\title{
An airway epithelial iNOS-DUOX2-thyroid peroxidase metabolome drives Th1/Th2 nitrative stress in human severe asthma
}

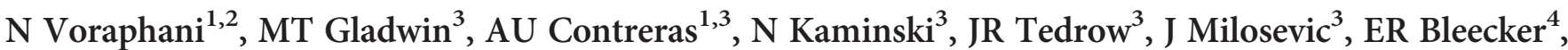 \\ DA Meyers ${ }^{4}$, A Ray ${ }^{1,3}$, P Ray ${ }^{1,3}$, SC Erzurum ${ }^{5}$, WW Busse ${ }^{6}$, J Zhao ${ }^{1,3}$, JB Trudeau ${ }^{1,3}$ and SE Wenzel ${ }^{1,3}$
}

Severe refractory asthma is associated with enhanced nitrative stress. To determine the mechanisms for high nitrative stress in human severe asthma (SA), 3-nitrotyrosine (3NT) was compared with Th1 and Th2 cytokine expression. In SA, high 3NT levels were associated with high interferon (IFN)- $\gamma$ and low interleukin (IL)-13 expression, both of which have been reported to increase inducible nitric oxide synthase (iNOS) in human airway epithelial cells (HAECs). We found that IL-13 and IFN- $\gamma$ synergistically enhanced iNOS, nitrite, and 3NT, corresponding with increased $\mathrm{H}_{2} \mathrm{O}_{2}$. Catalase inhibited whereas superoxide dismutase enhanced 3NT formation, supporting a critical role for $\mathrm{H}_{2} \mathrm{O}_{2}$, but not peroxynitrite, in 3NT generation. Dual oxidase-2 (DUOX2), central to $\mathrm{H}_{2} \mathrm{O}_{2}$ formation, was also synergistically induced by IL-13 and IFN- $\gamma$. The catalysis of nitrite and $\mathrm{H}_{2} \mathrm{O}_{2}$ to nitrogen dioxide radical $\left(\mathrm{NO}_{2}^{*}\right)$ requires an endogenous peroxidase in this epithelial cell system. Thyroid peroxidase (TPO) was identified by microarray analysis ex vivo as a gene distinguishing HAEC of SA from controls. IFN- $\gamma$ induced TPO in HAEC and small interfering RNA knockdown decreased nitrated tyrosine residues. Ex vivo, DUOX2, TPO, and iNOS were higher in SA and correlated with 3NT. Thus, a novel iNOS-DUOX2-TPO-NO: metabolome drives nitrative stress in HAEC and likely in SA.

\section{INTRODUCTION}

High levels of nitrated proteins, widely recognized to contribute to altered protein function and disease, are formed by the reaction of reactive nitrogen species (RNS) with tyrosine residues at the ortho position. ${ }^{1-2}$ These 3 -nitrotyrosines (3NTs) have been consistently reported in asthma, particularly in severe asthma (SA), ${ }^{3-5}$ where they have been associated with worsening airway obstruction. ${ }^{5}$ In human airway epithelial cells (HAECs), inducible nitric oxide synthase (iNOS) is the most important source of the nitrites and NO required for the formation of RNS. ${ }^{6,7}$ However, the oxidative metabolic pathways by which these iNOS products become RNS in human diseases such as asthma are less clear. Two pathways are generally believed to be important, one involving generation of superoxide radical and the other involving generation of $\mathrm{H}_{2} \mathrm{O}_{2}$.
Superoxide radical reacts with NO to form peroxynitrite, whereas $\mathrm{H}_{2} \mathrm{O}_{2}$ reacts with nitrite to form nitrogen dioxide radical $\left(\mathrm{NO}_{2}^{\circ}\right)$, either of which can nitrate tyrosine residues. ${ }^{1,8-12}$ In the case of the $\mathrm{H}_{2} \mathrm{O}_{2}$ pathway, however, an endogenous or exogenous peroxidase is also required for the formation of $\mathrm{NO}_{2}^{\circ}$.

Although the specifics of the oxidative stress pathways involved remain poorly understood in primary HAECs and in association with disease, it is likely that the family of NADPH oxidases and dual oxidases (DUOX) contribute. ${ }^{13,14}$ DUOX1 is the most abundant oxidase, whereas DUOX2 (also known as $\mathrm{NAD} / \mathrm{NADPH}$ thyroid oxidase) is reported to be the primary source of $\mathrm{H}_{2} \mathrm{O}_{2}$ in human airway epithelium. ${ }^{15,16}$ Both DUOX1 and DUOX2 were originally described in the thyroid where their $\mathrm{H}_{2} \mathrm{O}_{2}$ production is tightly regulated by thyroid peroxidase (TPO), and through interactions with TPO control the

\footnotetext{
${ }^{1}$ University of Pittsburgh Asthma Institute at UPMC and the University of Pittsburgh School of Medicine, Pittsburgh, Pennsylvania, USA. ${ }^{2}$ Department of Pediatrics, Faculty of Medicine, Chulalongkorn University, Bangkok, Thailand. ${ }^{3}$ Division of Pulmonary, Allergy, and Critical Care Medicine, Department of Medicine, University of Pittsburgh, Pittsburgh, Pennsylvania, USA. ${ }^{4}$ Center for Genomics and Personalized Medicine Research, Wake Forest School of Medicine, Winston-Salem, North Carolina, USA. ${ }^{5}$ Department of Pathobiology, Lerner Research Institute, Cleveland Clinic, Cleveland, Ohio, USA and ${ }^{6}$ Division of Allergy and Clinical Immunology, Department of Medicine, University of Wisconsin School of Medicine and Public Health, Madison, Wisconsin, USA. Correspondence: SE Wenzel (wenzelse@upmc.edu)
} 
formation of iodide radical essential for thyroid hormone synthesis. ${ }^{17,18}$ Despite the high levels of DUOX enzymes in human airway epithelium, and their known interactions with TPO in thyroid epithelium, TPO has been thought to be a thyroid-specific enzyme, not previously described in other epithelial structures. However, microarray analysis identified TPO in HAEC as the only peroxidase distinguishing SA from healthy controls (HCs) and milder asthma. In environments, such at the airway, where high levels of nitrite (as opposed to iodide) exist, DUOX2, interacting with its known partner in the thyroid epithelium, TPO, could enhance the production of $\mathrm{NO}_{2}^{\bullet}$ and 3 NT.

Although asthma, or at least an endotype of it, has consistently been thought of as a Th2 disease, iNOS expression has long been associated with Th1 immunity, with an earlier report linking airway epithelial Stat1 expression to iNOS. ${ }^{19}$ More recently, the Th2 cytokine interleukin (IL)-13 has also been shown to induce iNOS in vitro, ${ }^{7}$ and indeed, specific inhibitors of IL- 4 and/or IL-13 decrease levels of NO by $50 \%$ in exhaled breath of human asthmatics. ${ }^{20,21}$ Interestingly, long before iNOS was confirmed to be upregulated by Th2 cytokines alone, ${ }^{7}$ the combination of IL- 4 and interferon (IFN)- $\gamma$ were reported to jointly increase iNOS expression. ${ }^{22}$ Corticosteroid (CS) refractory SA has been associated with sustained elevations in iNOS expression, ${ }^{23}$ but the mechanisms for the high levels remain poorly understood, especially in view of the general effect of CSs to suppress Th2 immunity. Whether certain phenotypes of SA exhibit high levels of iNOS and exhaled NO because of a mixed Th1 and Th2 immune process is not yet clear. However, interestingly, several studies have shown that, similar to iNOS, DUOX enzymes are regulated by Th1 and Th2 cytokines. ${ }^{15-16,24}$

We therefore hypothesized that increases in nitrative stress in SA would be seen in the presence of increasing Th1 cytokines in association with a Th2 background. This combined Th1 and Th2 immunity would increase nitrative stress through synergistic increases in iNOS, and the expression and activation of the oxidizing enzyme DUOX2, in the presence of an unknown endogenous epithelial peroxidase. Thus, the biochemistry would involve a $\mathrm{H}_{2} \mathrm{O}_{2}$-nitrite-(endogenous) peroxidase nitration reaction. This hypothesis was addressed by determining (1) the levels of 3NT in association with Th1 and Th2 cytokines in SA; (2) the combined effects of Th1 (IFN$\gamma$ ) and Th2 (IL-13) cytokines on 3NT generation, and the central importance of nitrite and $\mathrm{H}_{2} \mathrm{O}_{2}$ to this process; (3) the critical importance of two novel proteins, DUOX2 and $\mathrm{TPO}$, to the $\mathrm{NO}_{2}^{\bullet}$ and nitrated protein formation; and (4) the recapitulation of this novel nitrative metabalome in SA epithelium.

\section{RESULTS}

\section{Subject demographics}

Fresh airway epithelial and bronchoalveolar lavage (BAL) cells were obtained from 91 subjects (Table 1). Twenty-three HCs, 23 mild-moderate asthma (MMA) and 29 SA subjects
Table 1 Demographics of subjects in study $(n=91)$

\begin{tabular}{|c|c|c|c|c|}
\hline & $\begin{array}{l}\text { Healthy } \\
\text { control } \\
(n=25)\end{array}$ & $\begin{array}{l}\text { Mild-moderate } \\
\text { asthma } \\
(\mathrm{n}=24)\end{array}$ & $\begin{array}{l}\text { Severe } \\
\text { asthma } \\
(n=42)\end{array}$ & $P$-values \\
\hline Female gender & 11 (44\%) & 17 (71\%) & $30(71 \%)$ & 0.05 \\
\hline Age $(\text { years })^{a}$ & $28(23-44)$ & $29(23-37)$ & $47(35-55)$ & $<0.001$ \\
\hline $\mathrm{FEV}_{1} \%$ predicted $^{\mathrm{a}}$ & $97(93-107)$ & $90(83-97)$ & $56(40-71)$ & $<0.001$ \\
\hline ICS & 0 & 14 of 24 & 42 of 42 & NA \\
\hline Atopy & 13 of 25 & 23 of 24 & 31 of 42 & 0.002 \\
\hline
\end{tabular}

$\mathrm{FEV}_{1} \%$ predicted, forced expiratory volume in $1 \mathrm{~s}$ expressed as a percentage of the predicted value; ICS, inhaled corticosteroid; NA, not applicable.

${ }^{\mathrm{a}}$ Median with 25th-75th percentiles.

contributed to BAL cell studies. Fresh epithelial cells were collected from $15 \mathrm{HCs}, 15 \mathrm{MMAs}$, and 31 SAs subjects. In vitro studies were performed on epithelial cells collected from $4 \mathrm{HCs}$, 16 MMAs, and 8 SAs subjects. SA subjects were older than control groups, had the lowest forced expiratory volume in $1 \mathrm{~s}$ $\left(\mathrm{FEV}_{1}\right)$ percent predicted despite lower levels of atopy than MMA. Thirty-five (83\%) of SA subjects used regular systemic CS. There were no differences in the demographics of the subgroups used for BAL, epithelial, or in vitro studies, nor between MMA by use of inhaled CS.

3NT is increased in SA lungs in association with increases in IFN- $\gamma$

Both fractional exhaled nitric oxide (FeNO) and epithelial 3NT levels were elevated in SA; however, 3NT better distinguished severity (Figure 1). Similarly, IFN- $\gamma$ mRNA was elevated in BAL cells from asthmatics and was highest in SA (median arbitrary units (25th-75th percentile), $\mathrm{HC}=0.2(0.09-0.36)$, $\mathrm{MMA}=0.4(0.22-2.48), \mathrm{SA}=3.1(0.70-6.27)$; overall $P<0.001$, age-adjusted $P<0.05$ for all comparisons, $n=53$ ). The levels of $3 \mathrm{NT}$ and IFN- $\gamma$ did not differ by atopy or CS use. In contrast, BAL cell IL-13 mRNA levels were $2-3 \log$ lower than IFN $-\gamma$ and did not differentiate the three groups $(\mathrm{HC}=0.005(0-0.103)$, $\mathrm{MMA}=0.010 \quad(0-0.033), \quad \mathrm{SA}=0.002 \quad(0-0.041) ; \quad$ overall $P=0.97, n=59)$. However, unlike IFN- $\gamma$, atopy was associated with IL-13 levels, with IL-13 being significantly higher in atopic $(0.057(0.003-0.139), n=8)]$ vs. non-atopic HC (0 (0-0.037), $n=8, P=0.046)$, suggesting a strong influence of background atopy alone (85\% of asthmatics were atopic thereby limiting comparisons). Thus, although low levels of IL-13 mRNA were present, and higher in atopic HCs, there were no increases with asthma or its severity. However, IFN- $\gamma$ mRNA levels increased with disease severity and in association with increasing 3NT levels.

The combination of Th1 and Th2 cytokines increases iNOS expression, and selectively increases nitrite in association with increases in 3NT over that of either cytokine alone

iNOS mRNA and protein. To confirm the combined impact of Th1 and Th2 cytokines on iNOS expression, cultured HAEC were stimulated for 8 days with/without IL-13 ( 1 or $10 \mathrm{ng} \mathrm{ml}^{-1}$ ) and then stimulated (or not) with IFN- $\gamma\left(10\right.$ or $100 \mathrm{ng} \mathrm{ml}^{-1}$ ) 
a

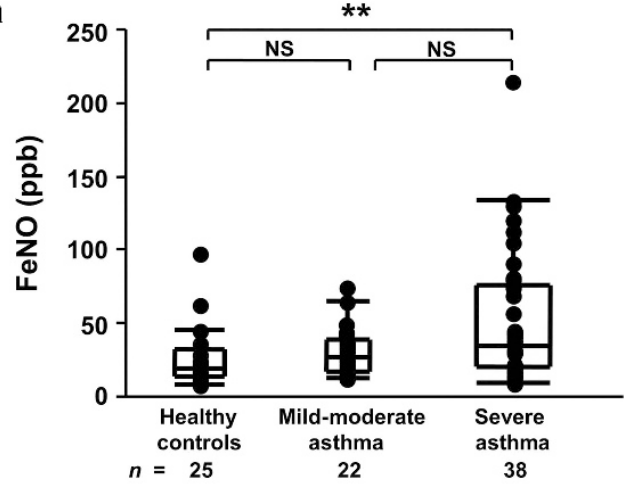

b

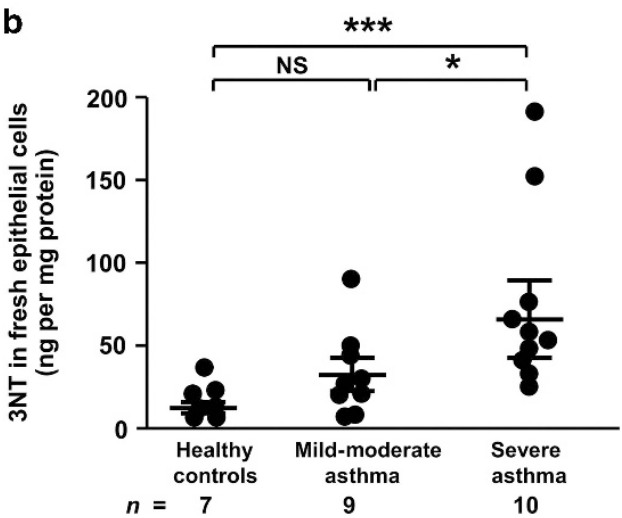

Figure 1 Elevated fractional exhaled nitric oxide (FeNO) and epithelia 3-nitrotyrosine (3NT) levels in severe asthma (SA). (a) FeNO levels were increased in SA compared with healthy control (HC). Overall $P<0.01$, ${ }^{* \star} P<0.01$, Kruskal-Wallis with Bonferroni correction; NS, not significant. Data are shown as median (25-75 percentiles). (b) 3NT levels were highest in fresh bronchial epithelial cells from SA compared with mildmoderate asthma (MMA) and HC. Overall $P<0.001,{ }^{\star} P<0.05$,

${ }^{* * *} P<0.001$, adjusted for age. Data are shown as mean \pm s.e.m.

for last $72 \mathrm{~h}$. iNOS mRNA and protein expression were highest in the presence of low-dose IL-13 (1 $\left.\mathrm{ng} \mathrm{ml}^{-1}\right)$ and either lowor high-dose IFN- $\gamma$ (Figure 2a,b).

iNOS activity. Nitrite and nitrate were used as markers of iNOS activity. Nitrite levels were consistently and synergistically higher with the combination of low-dose IL-13 and IFN- $\gamma$ (any dose) (Figure 2c). In contrast, nitrate did not increase with the combination (Supplementary Figure 1a online). Although nitrate was the predominant metabolite generated by both cytokines, IFN- $\gamma$ treatment resulted in a greater ratio of nitrite/nitrate (IFN- $\gamma 10 \mathrm{ng} \mathrm{ml}^{-1}$, $0.3 \pm 0.06$; IL-13 $10 \mathrm{ng} \mathrm{ml}^{-1}, 0.1 \pm 0.01 ; P<0.01, n=12$ ). High-dose IFN- $\gamma$ together with low-dose IL-13 similarly enhanced nitrite/nitrate levels compared with IL-13 alone $(P<0.025)$. However, there were no differences in nitrite/ nitrate ratios between treatment with IFN- $\gamma$ alone or IFN- $\gamma$ plus IL-13.

3NT expression. Both low- and high-dose IFN- $\gamma$ increased 3NT levels (control, $24 \pm 2$; IFN- $\gamma 10 \mathrm{ng} \mathrm{ml}^{-1}, 36 \pm 3$; IFN- $\gamma$ $100 \mathrm{ng} \mathrm{ml}^{-1}, 33 \pm 4 \mathrm{ng} \mathrm{mg}^{-1}$ protein; $P<0.017$ vs. control for both doses, $n=19$ ), whereas only low-dose IL-13 significantly increased their levels $(32 \pm 3, P<0.017$ vs. control). Similar to iNOS and nitrite, 3NT levels were synergistically enhanced in the presence of low-dose IL-13 and IFN- $\gamma$ (any dose) (Figure 2d). The percent increase in 3NT correlated with the percent increase in nitrite (from baseline) with low-dose IFN- $\gamma(r=0.75, P<0.01, n=11)$ and low-dose IFN- $\gamma$ plus low-dose IL-13 $(r=0.7, P<0.05)$, but not under other conditions.

\section{Generation of 3NT is dependent on $\mathrm{H}_{2} \mathrm{O}_{2}$ and nitrite as opposed to superoxide and NO}

To explore the oxidative pathways involved in $3 \mathrm{NT}$ generation, specifically peroxynitrite dependent vs. $\mathrm{H}_{2} \mathrm{O}_{2}$-nitrite-peroxidase dependent, catalase $\left(\mathrm{H}_{2} \mathrm{O}_{2}\right.$ scavenger $)$ or superoxide dismutase (SOD; superoxide scavenger) was added apically for $1 \mathrm{~h}$. Catalase addition decreased 3NT levels. Conversely, treatment with SOD paradoxically increased $3 \mathrm{NT}$ in the presence of low-dose IL-13 and low-dose IFN- $\gamma$ (Figure 3a), supporting the contribution of $\mathrm{H}_{2} \mathrm{O}_{2}$, but not superoxide, to epithelial 3NT formation. The addition of supplemental nitrite further increased the levels of $3 \mathrm{NT}$ in the presence of SOD (Supplementary Figure 3).

The role of $\mathrm{H}_{2} \mathrm{O}_{2} /$ nitrite-mediated tyrosine nitration was further investigated by adding exogenous nitrite in the presence/absence of IL-13 $\left(1 \mathrm{ng} \mathrm{ml}^{-1}\right)$ plus IFN- $\gamma\left(100 \mathrm{ng} \mathrm{ml}^{-1}\right)$. 3NT increased following addition of nitrite, an effect only marginally dependent on the presence of IL- $13+\mathrm{IFN}-\gamma$ $\left(12.6 \pm 1.99\right.$ vs. $6.5 \pm 1.82 \mathrm{ng} \mathrm{mg}^{-1}$ protein, $P=0.1$ for differences following $25 \mu \mathrm{m}$ nitrite addition, Figure $3 \mathbf{b}$ ). The increase in $3 \mathrm{NT}$ was attenuated $\sim 50 \%$ by catalase under all conditions, thereby confirming a role for $\mathrm{H}_{2} \mathrm{O}_{2}$.

IFN- $\gamma$ alone, and in combination with low-dose IL-13, increases $\mathrm{H}_{2} \mathrm{O}_{2}$ production that correlates with $3 \mathrm{NT}$ levels To determine whether Th1 or Th2 cytokines, alone or in combination, enhance $\mathrm{H}_{2} \mathrm{O}_{2}$ production, extracellular $\mathrm{H}_{2} \mathrm{O}_{2}$ production was measured apically after $1 \mathrm{~h}$ with PBS under the various IFN- $\gamma$ and IL-13 conditions. IFN- $\gamma$ robustly enhanced $\mathrm{H}_{2} \mathrm{O}_{2}$ production in a dose-dependent manner (control, $76 \pm 8$; IFN- $\gamma 10 \mathrm{ng} \mathrm{ml}^{-1}, 165 \pm 24$; IFN- $\gamma 100 \mathrm{ng} \mathrm{ml}^{-1}, 230 \pm 29 \mathrm{nM}$; overall $P<0.001, P<0.017$ for all comparisons, $n=6$ ). $\mathrm{H}_{2} \mathrm{O}_{2}$ also increased following high-dose, but not low-dose, IL-13 stimulation (IL-13 $1 \mathrm{ng} \mathrm{ml}^{-1}, 96 \pm 15$; IL-13 $10 \mathrm{ng} \mathrm{ml}^{-1}$, $179 \pm 28$; overall $P<0.01, P<0.017$ for $\mathrm{IL}-1310 \mathrm{ng} \mathrm{ml}^{-1}$ vs. control). Similar to $3 \mathrm{NT}$ expression, the combination of lowdose IL-13 and IFN- $\gamma$ (any dose) synergistically augmented apical $\mathrm{H}_{2} \mathrm{O}_{2}$ production (Figure 3c). Furthermore, $\mathrm{H}_{2} \mathrm{O}_{2}$ levels strongly correlated with $3 \mathrm{NT}(r=0.82, P<0.05, n=6)$ with stimulation by low-dose IL-13 plus low-dose IFN- $\gamma$, but not with low-dose IL-13 plus high-dose IFN- $\gamma(r=0.61, P=0.2)$. There were no correlations under other conditions (all $r<0.4$ ), perhaps owing to small sample size. As expected, and in parallel with the changes in $3 \mathrm{NT}, \mathrm{H}_{2} \mathrm{O}_{2}$ was decreased by catalase, whereas SOD increased $\mathrm{H}_{2} \mathrm{O}_{2}$ in the presence/absence of IL-13 and IFN- $\gamma$ (Figure 3d). 
a

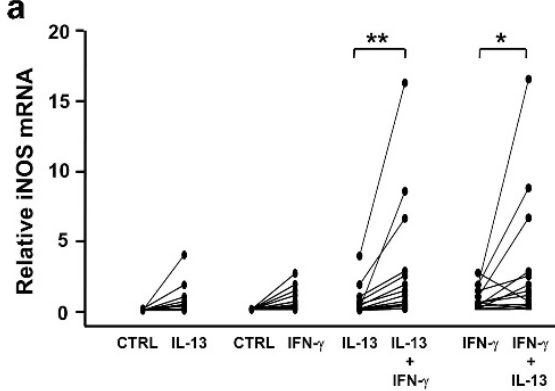

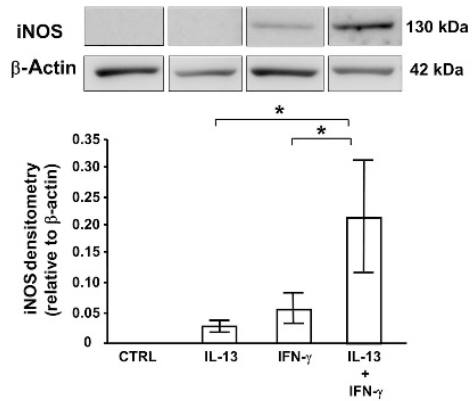
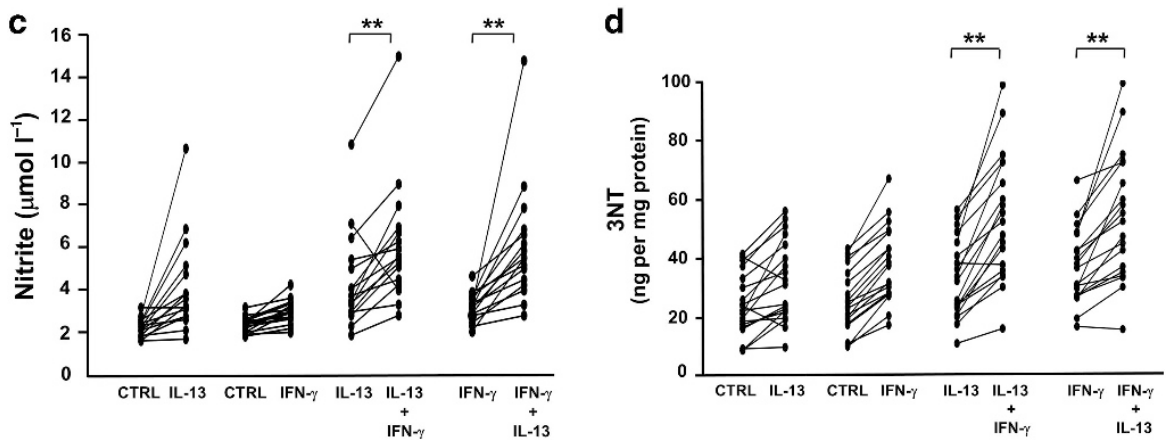

Figure 2 The combination of low-dose interleukin (IL)-13 and interferon (IFN)- $\gamma$ enhances inducible nitric oxide synthase (iNOS) expression, nitrite, and 3-nitrotyrosine (3NT) levels. Air-liquid interface (ALI)-cultured human airway epithelial cells (HAECs) were treated with low-dose IL-13 (1 $\mathrm{ng} \mathrm{ml}^{-1}$ ) or media for 8 days, with/without exposure to IFN- $\gamma\left(10 \mathrm{ng} \mathrm{ml}^{-1}\right)$ for final $72 \mathrm{~h}$. mRNA was harvested for real-time PCR. Total proteins were harvested for western blot analysis and 3NT measurement. Nitrite levels were measured in the lower supernatants. (a) iNOS mRNA, (b) iNOS protein, (c) nitrite, and (d) 3NT expression were augmented in the presence of IL-13 and IFN- $\gamma$ compared with either cytokine alone. $P$-value for interaction is $<0.05$ for all markers, ${ }^{\star} P<0.025,{ }^{\star \star} P<0.001 ; n=16,15,16,19$ for iNOS mRNA, iNOS protein, nitrite, and $3 N T$, respectively. Densitometry values are shown as mean \pm s.e.m.
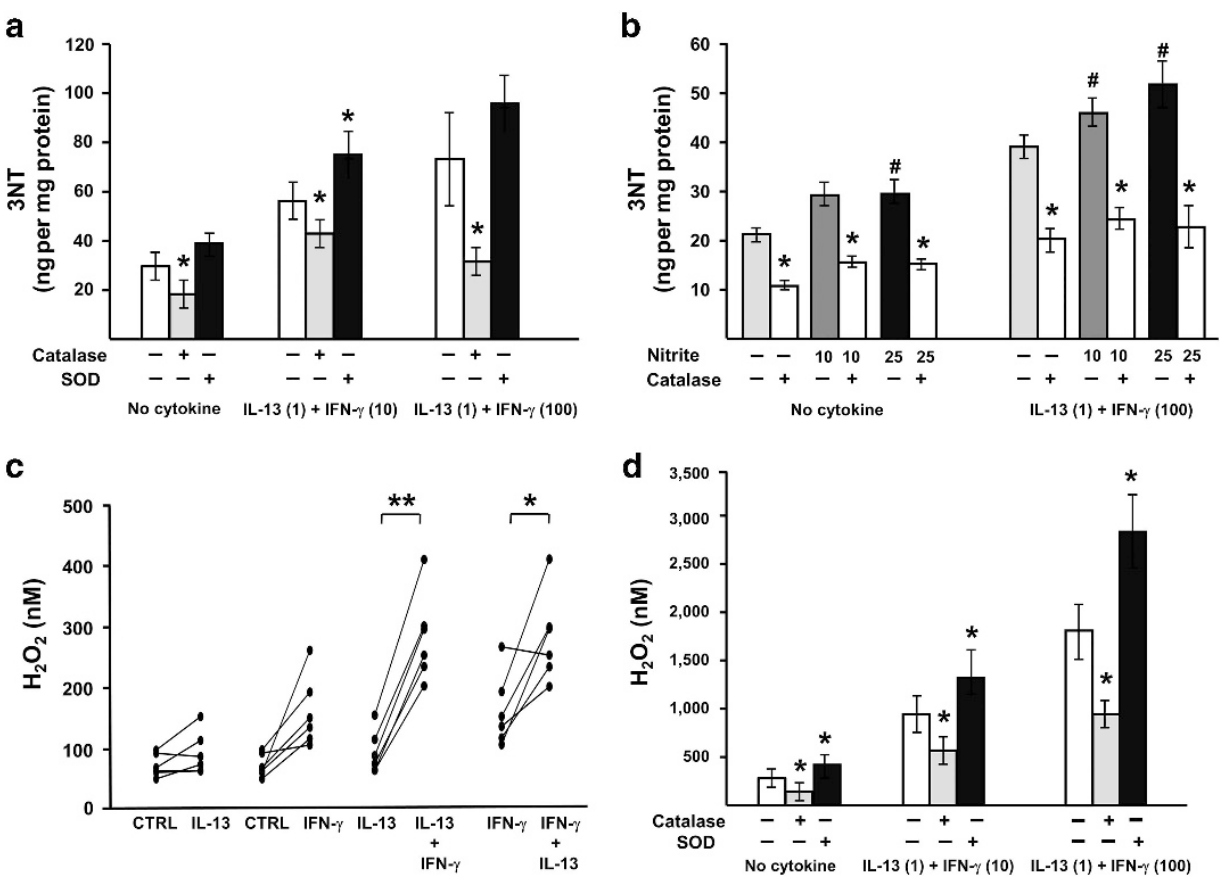

Figure 3 3-nitrotyrosine (3NT) expression changes in parallel with levels of $\mathrm{H}_{2} \mathrm{O}_{2}$ and nitrite. Air-liquid interface (ALI)-cultured human airway epithelial cells (HAECs) were treated with low-dose interleukin (IL)-13 $\left(1 \mathrm{ng} \mathrm{ml}^{-1}\right)$ or media for 8 days, with/without exposure to interferon (IFN)- $\gamma$ for the last $72 \mathrm{~h}$. Culture medium from the apical chamber was removed, and $100 \mu \mathrm{lPBS}$ with/without one of the following was added: catalase $\left(150 \mathrm{U} \mathrm{ml}^{-1}\right)$, superoxide dismutase (SOD) $\left(150 \mathrm{U} \mathrm{ml}^{-1}\right)$, nitrite $(10$ or $25 \mu \mathrm{M})$, or the combination of catalase and nitrite. After $1 \mathrm{~h}$ incubation, extracellular $\mathrm{H}_{2} \mathrm{O}_{2}$ levels were measured in the upper chamber supernatants. Total proteins were harvested for 3NT measurement. (a) Addition of catalase decreased 3 NT levels in the presence/absence of IL-13 and IFN- $\gamma$, whereas SOD increased 3NT when cells were stimulated with IL-13 and IFN- $\gamma\left(10 \mathrm{ng} \mathrm{ml}{ }^{-1}\right)$. ${ }^{*} P<0.05$ vs. no catalase/SOD. (b) Exogenous nitrite upregulated 3NT expression, whereas catalase attenuated this effect. ${ }^{\#} P<0.017$ vs. no nitrite, ${ }^{\star} P<0.05$ vs. no catalase. (c) $\mathrm{H}_{2} \mathrm{O}_{2}$ levels were enhanced in the presence of low-dose IL-13 and IFN- $\gamma\left(10 \mathrm{ng} \mathrm{ml}^{-1}\right)$ compared with either cytokine alone. $P$-value for interaction is $<0.05,{ }^{\star} P<0.025$, ${ }^{\star \star} P<0.001$. (d) $\mathrm{H}_{2} \mathrm{O}_{2}$ production followed a similar trend to $3 \mathrm{NT}$, with the levels decreasing with catalase and increasing with SOD. ${ }^{\star} P<0.05$ vs. no catalase/SOD. All $n=6$. Data are presented as mean \pm s.e.m. 
Expression of the $\mathrm{H}_{2} \mathrm{O}_{2}$-producing enzyme DUOX2 is increased by IFN- $\gamma$, alone and in combination with IL-13, whereas knockdown reduces $\mathrm{H}_{2} \mathrm{O}_{2}$ and $3 \mathrm{NT}$ levels

DUOX2 mRNA and protein. As previously reported, ${ }^{15}$ IFN- $\gamma$ dose-dependently increased DUOX2 mRNA and protein expression from HAEC (Supplementary Figure 1b,c). In the presence of low-dose IL-13, there was a synergistic increase in DUOX2 mRNA and protein compared with IFN- $\gamma$ alone (any dose) (Figure 4a,b).

Knockdown of DUOX2. To confirm the role of DUOX2 in the increase in $\mathrm{H}_{2} \mathrm{O}_{2}$ and $3 \mathrm{NT}$, small interfering RNA (siRNA) knockdown of DUOX2 was used in the presence/absence of combined IL-13 $\left(1 \mathrm{ng} \mathrm{ml}^{-1}\right)$ and IFN- $\gamma\left(100 \mathrm{ng} \mathrm{ml}^{-1}\right)$. Highdose IFN- $\gamma$ was used because it gave the most robust increase in DUOX2. DUOX2-targeted siRNA decreased DUOX2 mRNA $(5.6 \pm 1.38$ vs. $6.1 \pm 1.42, P<0.05, n=3)$ and protein expression following stimulation with IL-13 and IFN- $\gamma$ (Figure 4c). Knockdown of DUOX2 led to $\sim 50 \%$ lower $\mathrm{H}_{2} \mathrm{O}_{2}$ and $3 \mathrm{NT}$ levels as compared with scramble siRNA (Figure 4d,e).

TPO, an endogenous epithelial peroxidase, is identified as a highly differentiating gene in epithelial microarrays

A heme peroxidase is required to generate the $\mathrm{NO}_{2}^{\bullet}$ that nitrates tyrosine residues to form $3 \mathrm{NT}$. The presence of $3 \mathrm{NT}$ in the isolated cell culture system suggests the presence of an endogenous epithelial peroxidase. A large-scale microarray data set generated from airway epithelial brushings of asthmatics and HC (Subject Demographics in Supplementary Table 1) recruited through the Severe Asthma Research Program (SARP) network was probed for the presence of peroxidases. When comparing the subjects with SA to HC and looking at 27,958 genes, the differentially expressed gene with the sixth highest linear-fold ratio difference was TPO with a fold ratio of 3.65 (Figure 5). No other peroxidases were differentially expressed between SA and HC.

HAEC endogenously express TPO, a heme peroxidase, that is primarily enhanced by Th1 cytokine IFN- $\gamma$

IFN- $\gamma$ stimulation enhanced both TPO mRNA and protein expression (Figure 6a,b). TPO in air-liquid interface (ALI)cultured cells consistently appeared as a single $\sim 75-80 \mathrm{kDa}$ band $(25-35 \mathrm{kDa}$ less than the previously reported $\sim 100-$ $110 \mathrm{kDa}$ full-length protein), suggesting a potential new TPO isoform expressed in HAEC. TPO mRNA, but not protein, was induced by high-dose IL-13 (Figure 6c). Unlike DUOX2 and iNOS, only high-dose $\left(100 \mathrm{ng} \mathrm{ml}^{-1}\right)$, but not low-dose $\left(10 \mathrm{ng} \mathrm{ml}^{-1}\right)$, IFN- $\gamma$ in combination with low-dose IL-13 further increased TPO mRNA (overall $P<0.001, P<0.025$ between combined low-dose IL-13 and high-dose IFN- $\gamma$ vs. IL-13 alone or IFN- $\gamma$ alone, $n=9$ ); however, no synergistic effect on protein was observed (Figure 6d,e). TPO mRNA a

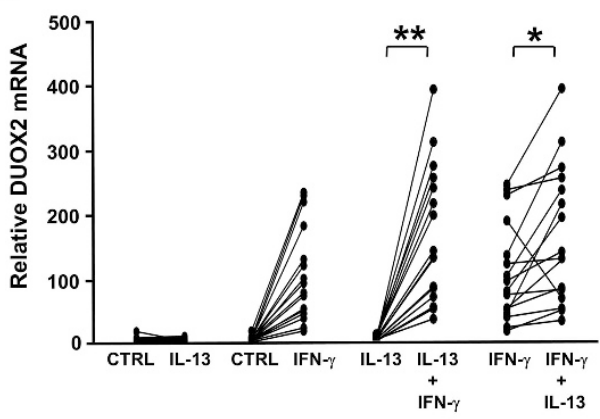

C

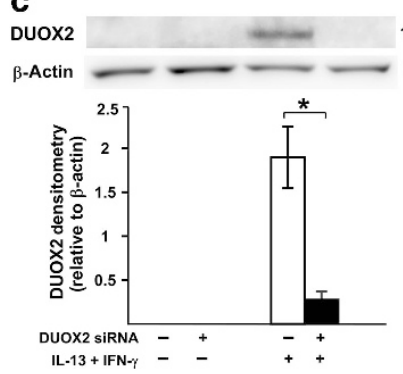

b

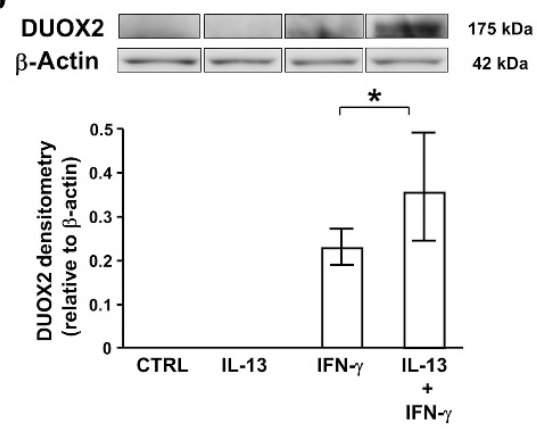

e
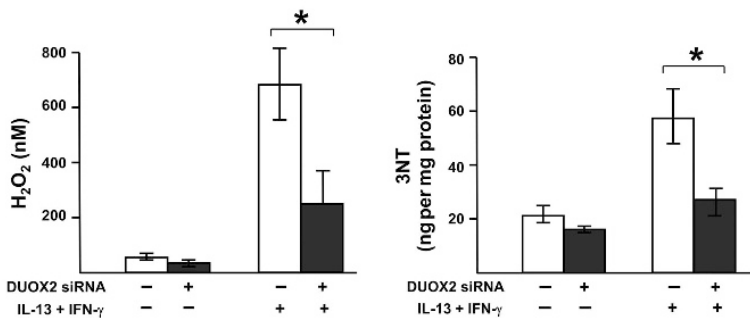

Figure 4 Interferon (IFN)- $\gamma$ in combination with low-dose interleukin (IL)-13 enhances dual oxidase-2 (DUOX2) expression, and knockdown of DUOX2 decreases $\mathrm{H}_{2} \mathrm{O}_{2}$ as well as 3-nitrotyrosine (3NT) levels. Air-liquid interface (ALI)-cultured human airway epithelial cells (HAECs) were stimulated for 8 days with or without low-dose IL-13 $\left(1 \mathrm{ng} \mathrm{ml}^{-1}\right)$, and then stimulated (or not) with IFN- $\gamma\left(10 \mathrm{ng} \mathrm{ml}^{-1}\right)$ for the last $72 \mathrm{~h}$. For knockdown experiment, ALI-cultured cells transfected with DUOX2 siRNA were stimulated with IL-13 $\left(1 \mathrm{ng} \mathrm{ml}^{-1}\right)$ and IFN- $\gamma\left(100 \mathrm{ng} \mathrm{ml}^{-1}\right)$ for $48 \mathrm{~h}$. The culture medium from the upper chamber was removed and $100 \mu \mathrm{l}$ PBS was added. Extracellular $\mathrm{H}_{2} \mathrm{O}_{2}$ production was measured in the upper chamber supernatants after $1 \mathrm{~h}$ incubation. mRNA was harvested for real-time PCR. Total proteins were harvested for western blot analysis and 3 NT measurement. In the concomitant presence of IL-13 and IFN- $\gamma$, there were increases in (a) DUOX2 mRNA and (b) DUOX2 protein over that of either IFN- $\gamma$ or IL-13 alone. $P$-value for interaction is $<0.001$ for both markers, ${ }^{*} P<0.025$, ${ }^{* \star} P<0.001 ; n=16$ for DUOX2 mRNA, $n=11$ for DUOX2 protein. (c) Western blot demonstrating DUOX2 knockdown in the presence of IL-13 and IFN- $\gamma$ stimulation. Inhibition of DUOX2 by siRNA transfection suppressed $(\mathbf{d}) \mathrm{H}_{2} \mathrm{O}_{2}$ and $(\mathbf{e}) 3 \mathrm{NT}$ production induced by IL-13 and IFN- $\gamma$. ${ }^{*} P<0.05, n=4$. Data are presented as mean \pm s.e.m. siRNA, small interfering RNA. 
correlated with DUOX2 mRNA under combined low-dose IL-13 and low-dose IFN- $\gamma(r=0.92, P<0.001, n=9)$. Under low-dose IL-13 and high-dose IFN- $\gamma$, TPO mRNA levels in cultured cells from SA $(n=4)$ tended to be higher than

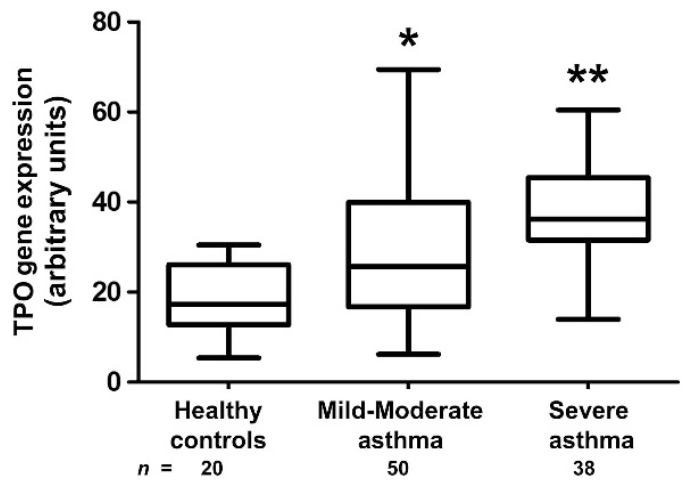

Figure 5 Thyroid peroxidase (TPO) is identified as a highly differentiating gene in epithelial microarrays. Box-whisker plot showing linear-scale microarray gene expression of TPO for healthy control $(\mathrm{HC})$, mild-moderate asthma (MMA), and severe asthma (SA). The boxes represented the mean and s.d., and the whiskers represented the minimum and maximum values of the distribution. ${ }^{*} P<0.05$, two-tailed $t$-test vs. $\mathrm{HC}$; ${ }^{\star \star} P<0.05$, two-tailed $t$-test vs. $\mathrm{HC}$ and MMA. those from non-severe subjects (one HC and four MMA, $P=0.07)$.

\section{Knockdown of TPO decreases 3NT expression confirming its involvement}

To investigate the role of TPO in 3NT generation, cells were transfected with TPO siRNA in the presence/absence of combined IL-13 $\left(1 \mathrm{ng} \mathrm{ml}^{-1}\right)$ and IFN- $\gamma\left(100 \mathrm{ng} \mathrm{ml}^{-1}\right.$, as used for DUOX2 siRNA experiments). TPO siRNA reduced TPO protein and 3NT (Figure 7), thereby supporting the contribution of TPO to epithelial 3NT formation.

\section{DUOX2 and TPO expression are increased in fresh bronchial epithelial cells from SA}

We confirmed previously reported increase in iNOS expression in epithelial cells of asthma, including SA (Supplementary Figure 2). ${ }^{19,23}$ Similarly, DUOX2 and TPO expression were highest in SA compared with MMA and HC (Figure 8). Use of inhaled CS did not impact results. DUOX2 mRNA in fresh epithelial cells correlated with IFN- $\gamma$ mRNA in BAL cells $(r=0.58, P<0.001, n=30)$. Positive correlations between DUOX2 and iNOS mRNA $(r=0.46, P<0.001, n=48)$, DUOX2 and 3NT ( $r=0.57, P<0.01, n=23)$, as well as DUOX2 and TPO mRNA ( $\rho=0.46, P<0.05, n=19)$ were observed. 3NT correlated with iNOS mRNA $(r=0.45, P<0.05, n=26)$ and a

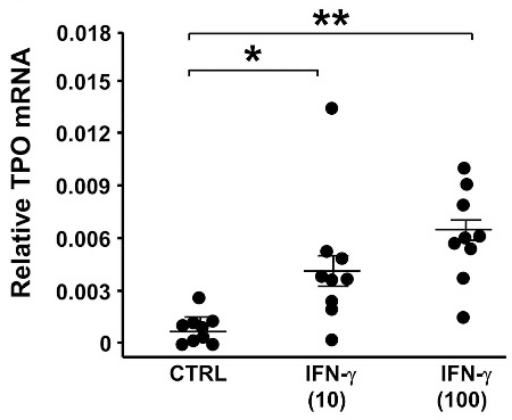

b

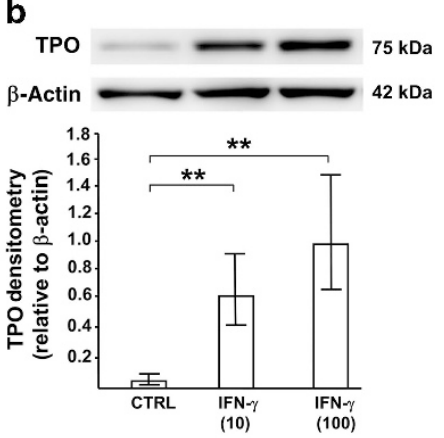

C

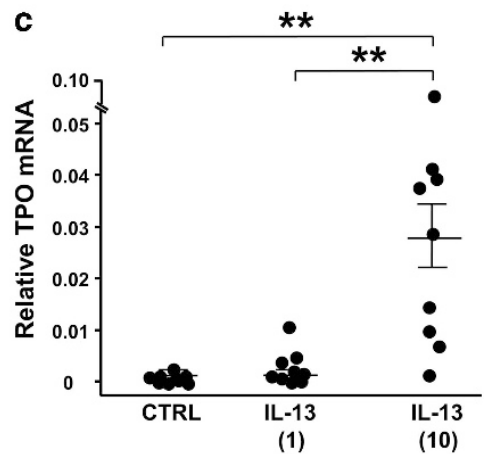

d

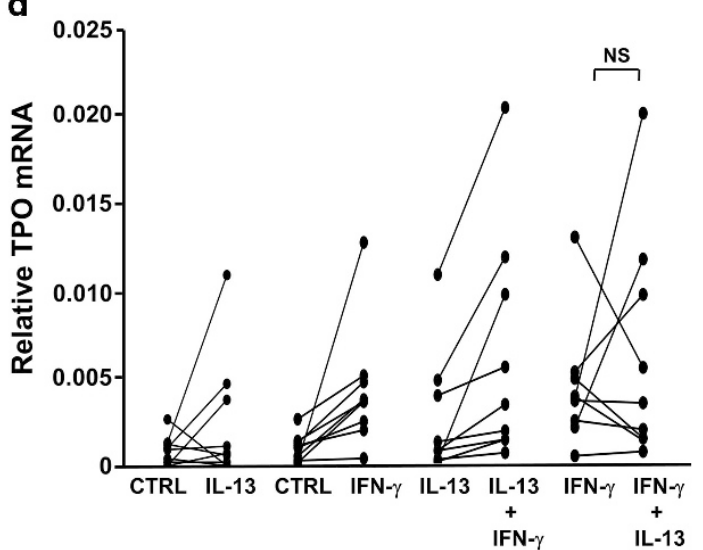

e

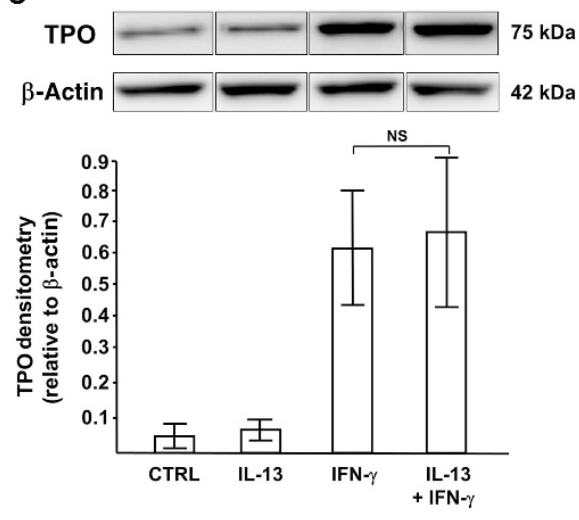

Figure 6 Thyroid peroxidase (TPO) expression is enhanced by interferon (IFN)- $\gamma$. Air-liquid interface (ALI)-cultured cells were treated with interleukin (IL) -13 or media for 8 days, with/without exposure to IFN- $\gamma$ for final $72 \mathrm{~h}$. mRNA was harvested for real-time PCR and total proteins were harvested for western blot analysis. Both concentrations of IFN- $\gamma\left(10,100 \mathrm{ng} \mathrm{ml}^{-1}\right)$ induced (a) TPO mRNA and (b) protein, whereas (c) only high-dose IL-13

$\left(10 \mathrm{ng} \mathrm{ml}^{-1}\right)$, but not low-dose $\left(1 \mathrm{ng} \mathrm{ml}^{-1}\right)$ enhanced TPO mRNA. Overall $P<0.001,{ }^{\star} P<0.017,{ }^{\star \star} P<0.001$. Unlike inducible nitric oxide synthase (iNOS) and dual oxidase-2 (DUOX2), IFN- $\gamma\left(10 \mathrm{ng} \mathrm{ml}^{-1}\right)$ in combination with low-dose IL-13 $\left(1 \mathrm{ng} \mathrm{ml}^{-1}\right)$ did not further increase (d) TPO mRNA or (e) protein. $n=9$ for TPO mRNA, $n=8$ for TPO protein. Results are shown as mean \pm s.e.m. 

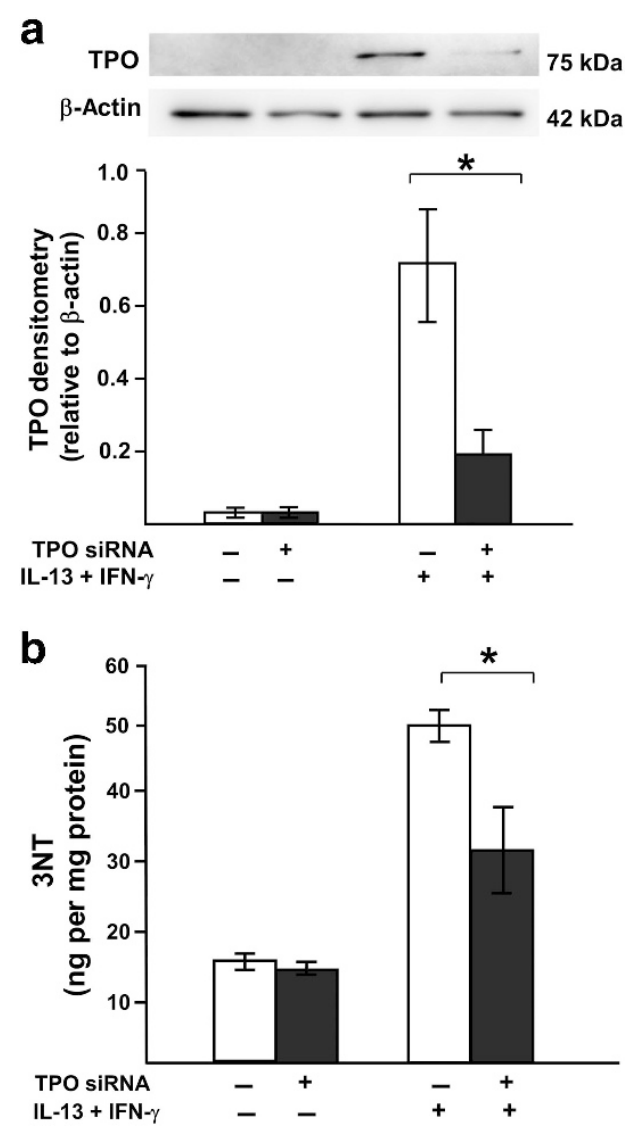

Figure 7 Thyroid peroxidase (TPO) siRNA reduces 3-nitrotyrosine (3NT) formation. Air-liquid interface (ALI)-cultured cells transfected with TPO siRNA were stimulated with interleukin (IL)-13 $\left(1 \mathrm{ng} \mathrm{ml}^{-1}\right)$ and interferon (IFN)- $\gamma\left(100 \mathrm{ng} \mathrm{ml}^{-1}\right)$ for $48 \mathrm{~h}$. Total proteins were harvested for western blot analysis and 3NT measurement. (a) Western blot of TPO knockdown in the presence of IL-13 and IFN- $\gamma$ stimulation. (b) Suppression of TPO by siRNA transfection reduced 3NT production induced by IL-13 and IFN- $\gamma$. ${ }^{\star} P<0.05$, one-tailed $t$-test, $n=3$. Data are presented as mean \pm s.e.m. siRNA, small interfering RNA.
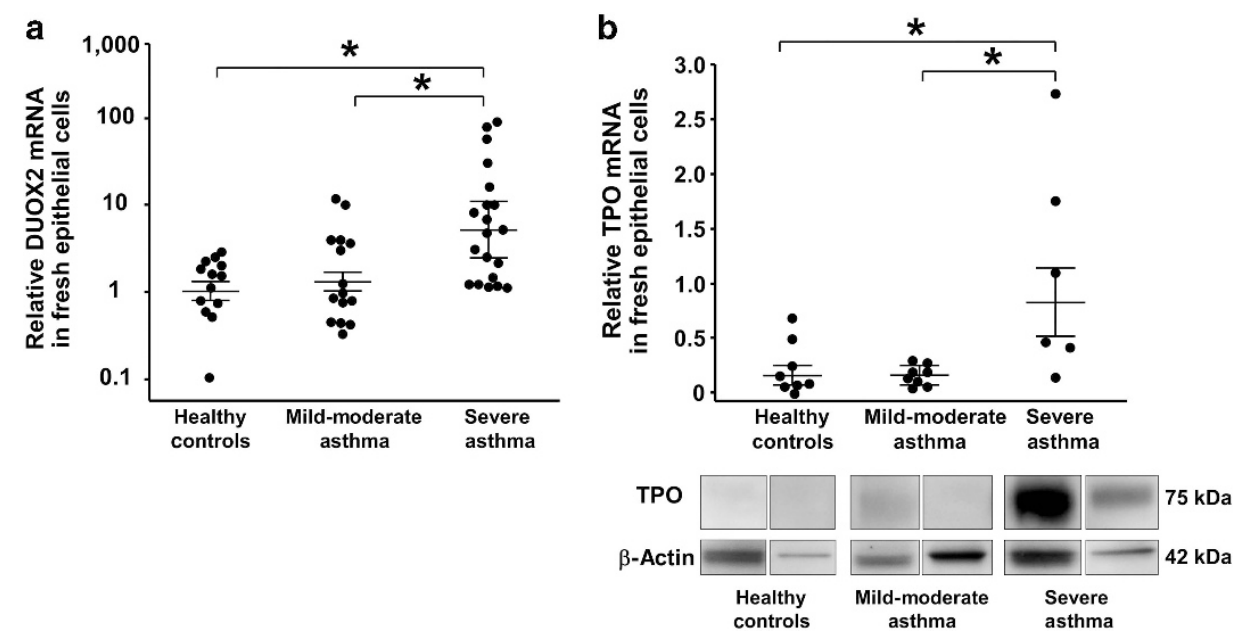

FeNO $(\rho=0.48, P<0.05, n=26)$. TPO mRNA did not correlate with $3 \mathrm{NT}$. No correlation was found between BAL IL-13 mRNA and epithelial 3NT, DUOX2, and TPO mRNA.

\section{DISCUSSION}

This present study identifies a highly novel metabolic pathway by which combined Th1 and Th2 cytokines, as observed in SA, enhance nitrative stress in HAEC. It links these in vitro data to in vivo data, supporting the relevance of these findings to more severe forms of asthma, where the degree of airway nitrative (and oxidative stress) is greatest. The Th1 cytokine (IFN- $\gamma$ ), together with a Th2 (IL-13) inflammatory background, not only amplifies epithelial DUOX2 expression leading to a robust increase in its reactive oxygen species (ROS) product, $\mathrm{H}_{2} \mathrm{O}_{2}$, but also potentiates the production of one specific iNOS-generated nitrogen species, nitrite, required for reactions with $\mathrm{H}_{2} \mathrm{O}_{2}$. Reaction of these two specific molecules, $\mathrm{H}_{2} \mathrm{O}_{2}$ and nitrite, when catalyzed by peroxidases, specifically the novel airway epithelial peroxidase TPO identified here, forms $\mathrm{NO}_{2}^{\circ}$, a powerful reactive nitrogen radical that nitrates tyrosine residues identified as $3 \mathrm{NT}$. Thus, generation of $3 \mathrm{NT}$ in this airway epithelial culture system occurs primarily through a novel iNOS/DUOX2/TPO nitrite oxidation metabolome, and not through a superoxide-dependent peroxynitrite reaction (Figure 9). Thus, in addition to its well-known beneficial oxidative function in innate pulmonary host defense, DUOX2 appears critical to airway nitrative-oxidative injury through this $\mathrm{H}_{2} \mathrm{O}_{2}$-induced 3NT formation. Collectively, we propose that the concomitant presence of Th1 and Th2 cytokines, as observed in SA, augments airway nitro-oxidative stress through novel pathways, thereby contributing to epithelial dysfunction and worsening asthma.

In a previous study, we reported significant increases in iNOS expression in SA, despite high-dose inhaled and even systemic CS use. ${ }^{23}$ Although this increase in iNOS is likely partly due to persistent Th2 cytokines, such as IL-13 (known to induce iNOS), ${ }^{7}$ IL-13 and IL-4 have been difficult to measure in
Figure 8 Enhanced dual oxidase-2 (DUOX2) and thyroid peroxidase (TPO) mRNA in epithelial cells from severe asthma (SA). Expression of (a) DUOX2 mRNA and (b) TPO mRNA were increased in fresh bronchial epithelial cells from SA compared with mild-moderate asthma (MMA) and healthy control (HC). Overall $P<0.05$ for both markers, ${ }^{*} P<0.05$, adjusted for age. Results are shown as mean \pm s.e.m.

b 


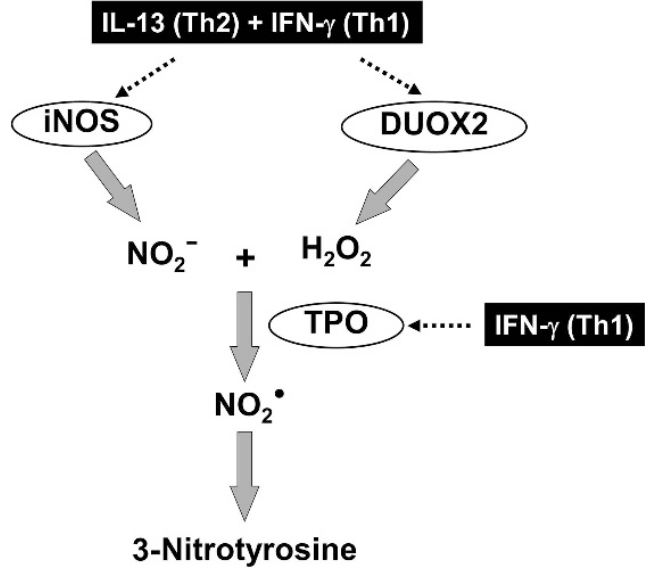

Figure 9 Proposed biochemical pathway of 3-nitrotyrosine (3NT) generation in airway epithelia.

consistently higher quantities in severe CS-treated asthmatics. However, asthmatics have higher than normal levels of IFN- $\gamma$ in BAL that increase with allergen exposure, with evidence for induction of IFN- $\gamma$ signal transduction pathways. ${ }^{19}$ IFN- $\gamma$ gene expression in the airways was similarly evaluated in this study revealing significantly higher levels in SA compared with milder asthmatics, supporting a role of this cytokine in iNOS expression as well. In HAEC, IFN- $\gamma$ synergized with IL-13 to enhance iNOS expression. Thus, it is plausible that the presence of IL-13, together with IFN- $\gamma$, might have a large role in expression of iNOS in SA. Furthermore, the increase in INOS was associated with increases in both FeNO and 3NT. Increases in 3NT expression necessitate the additional presence of ROS. Excessive ROS (and RNS) has been consistently reported in the airways of asthmatics. ${ }^{3-5,25-27}$ These ROS contribute to the formation of RNS, which then nitrate tyrosine residues forming $3 \mathrm{NT}$.

There are two well-described pathways for protein nitration. One uses peroxynitrite, which is the reaction product of $\mathrm{NO}$ and superoxide, and the other uses $\mathrm{NO}_{2}^{\circ}$ formed by the reaction of nitrite and $\mathrm{H}_{2} \mathrm{O}_{2}$, typically in the presence of a heme peroxidase. ${ }^{8-12}$ Although tyrosine nitration in asthmatic airways is generally attributed to peroxynitrite, there is substantial evidence supporting the generation of $3 \mathrm{NT}$ through peroxynitrite-independent mechanisms. ${ }^{8-12}$ For this pathway to be active, typically, the presence of heme peroxidases, such as those found in eosinophils (eosinophil peroxidase) and neutrophils (myeloperoxidase) is believed to be mandatory. ${ }^{9-12,28-30}$ Although these enzymes contribute to the generation of bromous and hypochlorous acid through interactions with halides, in the presence of nitrite, eosinophil peroxidase and myeloperoxidase also drive $3 \mathrm{NT}$ formation via oxidation of nitrite to $\mathrm{NO}_{2}{ }^{\cdot}{ }^{9-12,27-30}$ The data from this study strongly suggest that the $3 \mathrm{NT}$ measured both in vitro and ex vivo is formed by this peroxidase $/ \mathrm{H}_{2} \mathrm{O}_{2} / \mathrm{NO}_{2}^{-}$system. However, as the isolated epithelial cell culture system used here does not contain granulocytes, it suggested that alternate novel and non-inflammatory cell-linked peroxidase sources also exist and contribute.
Elevated $\mathrm{H}_{2} \mathrm{O}_{2}$ in exhaled breath has been observed in various airway diseases including asthma. ${ }^{26}$ The primary enzyme contributing to $\mathrm{H}_{2} \mathrm{O}_{2}$ in airway epithelium is reported to be DUOX2. ${ }^{15-16}$ Intriguingly, DUOX2 (similar to iNOS) was strongly upregulated in response to IFN- $\gamma$ in ALI cell culture, was elevated in freshly obtained airway epithelial cells from SA, and strongly correlated with IFN- $\gamma$ in this compartment. Thus, we hypothesized that IFN- $\gamma$, alone or in combination with the Th2 cytokine IL-13, might be contributing to the significantly higher levels of $3 \mathrm{NT}$ in SA reported here.

In fact, in an ALI epithelial system, IL-13 and IFN- $\gamma$ in combination induced the higher expression of iNOS and DUOX2 than either cytokine alone, with the effect being most consistently seen in the presence of a low IL-13 concentration, as might be seen in patients treated with high-dose CS. DUOX2 expression was associated with increases in activation as measured by $\mathrm{H}_{2} \mathrm{O}_{2}$. In the case of iNOS, while total $\mathrm{NO}$ metabolites increased only slightly, the generation of nitrite specifically distinguished the combination from IL-13 alone. Elevated levels of nitrite have been found in exhaled condensate of asthmatics, supporting the activity of this pathway in vivo in enhancing nitro-oxidative stress. ${ }^{31}$

As nitrite specifically interacts with $\mathrm{H}_{2} \mathrm{O}_{2}$ to form $\mathrm{NO}_{2}^{\bullet}$, and DUOX2, unlike the other NADPH oxidases, exclusively generates $\mathrm{H}_{2} \mathrm{O}_{2}$, ${ }^{13}$ the relative importance of $\mathrm{H}_{2} \mathrm{O}_{2}$ (as compared with superoxide) for the generation of $3 \mathrm{NT}$ was addressed by adding SOD (to metabolize superoxide) and catalase (to metabolize $\mathrm{H}_{2} \mathrm{O}_{2}$ ). The addition of catalase significantly decreased both $\mathrm{H}_{2} \mathrm{O}_{2}$ and $3 \mathrm{NT}$, whereas the addition of SOD paradoxically increased $\mathrm{H}_{2} \mathrm{O}_{2}$ and $3 \mathrm{NT}$, likely because of the metabolism of superoxide to $\mathrm{H}_{2} \mathrm{O}_{2}$, thereby increasing the levels even further. Thus, in this system, $\mathrm{H}_{2} \mathrm{O}_{2}$ contributed to the generation of $3 \mathrm{NT}$, whereas superoxide clearly did not. In fact, these results, in human cells, may account for the variable success of SOD mimetic drugs for asthma. ${ }^{32,33}$

In this airway epithelial system, there were strong correlations between $3 \mathrm{NT}$ and $\mathrm{H}_{2} \mathrm{O}_{2}$, as well as DUOX2. When $\mathrm{H}_{2} \mathrm{O}_{2}$ levels were reduced by DUOX2 knockdown, 3NT levels decreased as well, confirming the importance of $\mathrm{H}_{2} \mathrm{O}_{2}$ and DUOX2 to increases in $3 \mathrm{NT} . \mathrm{H}_{2} \mathrm{O}_{2}$ is known to be a key ROS that reacts with heme peroxidases to form ferryl intermediates, specifically oxidizing nitrite to generate $\mathrm{NO}_{2} \cdot{ }^{34}$ With its high affinity for the iron center in these peroxidases, nitrite enhances the oxidizing capacity of peroxidase $/ \mathrm{H}_{2} \mathrm{O}_{2}{ }^{35}$ This is supported by our findings that the addition of nitrite resulted in increased $3 \mathrm{NT}$ expression that tends to be more pronounced in the presence of $\mathrm{H}_{2} \mathrm{O}_{2}$. These results strongly predicted the presence of a yet unidentified heme peroxidase, endogenous to the airway epithelium, which could contribute to enhanced oxidative stress, even in the absence of inflammatory cells.

Intriguingly, DUOX2 was first described in thyroid epithelium and has alternatively been known as thyroid oxidase. ${ }^{36}$ Although DUOX2 is reported to have its own peroxidase activity ${ }^{24}$ in the thyroid epithelium it co-localizes with TPO. Although not previously reported in lung tissue or any epithelium outside the thyroid, TPO was highly expressed in epithelial 
microarrays, and, in fact, was the sixth most differentiating gene between SA and HC, and the only peroxidase differentially expressed in the epithelium. Quantitative real-time PCR of epithelial cell brushing, western blot identification of protein, and selective knockdown by TPO siRNA confirmed that TPO was not only present in the airway epithelium but also increased in SA. Interestingly, western blot analysis for TPO revealed a single band at $\sim 75-80 \mathrm{kDa}, \sim 25-35 \mathrm{kDa}$ less than the reported full-length TPO, ${ }^{37}$ thereby suggesting that a novel isoform may be present in the airway epithelium. Given the widely appreciated diversity of human TPO, including a variant between 80 and $85 \mathrm{kDa}$, this possibility is highly plausible. ${ }^{38}$ Presently, at least seven transcript variants encoding TPO isoforms, ranging from 760 to 933 amino acids have been identified. ${ }^{38}$ The identity and functional significance of this airway TPO was further addressed by silencing it with siRNA, which resulted in reduced $3 \mathrm{NT}$ production, supporting TPO as a key endogenous peroxidase in epithelial 3NT generation. In the thyroid, TPO promotes the production of reactive iodine species through its interaction (and co-localization) with DUOX2-induced $\mathrm{H}_{2} \mathrm{O}_{2}$ and iodide. These studies suggest that similar interactions occur in the airway epithelium, whereby TPO uses DUOX2-derived $\mathrm{H}_{2} \mathrm{O}_{2}$ to catalyze oxidation of nitrite (instead of iodide) to subsequently form $\mathrm{NO}_{2}^{*}$, which then nitrates tyrosine residues. The upregulation of both DUOX2 and TPO by IFN- $\gamma$ in the presence of IL-13 (or IFN- $\gamma$ alone) emphasizes that multiple immune pathways can increase nitrooxidative stress in asthmatic epithelial cells, even perhaps in the absence of an active Th2/eosinophilic process. Whether activation of this pathway represents a process common to both Th2-Hi and Th2-Lo (or non-eosinophilic) asthma awaits further study. ${ }^{39}$

Although a knockout mouse might be useful to understand the functional contribution of the iNOS/DUOX2/TPO/3NT metabalome to the pathobiology of asthmatic inflammation, this approach is not possible given the opposing effects of Th1 and Th2 cytokines on iNOS expression in mice compared with humans, and the likely differences in the cell source of the iNOS. In mice, IL- 4 and IL-13, alone or in combination with IFN- $\gamma$, inhibit iNOS expression and nitrite production. ${ }^{40,41}$ Further, iNOS in mice is found in the airway epithelium and alveolar macrophage, whereas in asthmatic humans, the epithelium is the primary source. ${ }^{6,19,23}$ Overall, these factors limit the utility of the study of iNOS-DUOX interactions in murine models.

Post-translational modification of epithelial proteins by ROS or RNS can alter their expression, structure, and biological function. Studies using HAECs show that $\mathrm{H}_{2} \mathrm{O}_{2}$ induces aberrant phosphorylation of epidermal growth factor (EGF) receptor, a receptor involved in wound repair, resulting in impaired canonical dimerization, trafficking, and degradation. ${ }^{42}$ Similarly, nitration of the EGF-like domain of neuregulin-1, an EGF-related growth factor, diminishes its ability to bind and activate the EGF receptor. ${ }^{43}$ Further, $\mathrm{H}_{2} \mathrm{O}_{2}$-mediated tyrosine nitration could also promote CS insensitivity through decreased histone deacetylase- 2 activity, resulting in enhanced inflammatory cytokine production. ${ }^{44}$ Nitrotyrosine incorp- orated into alpha-tubulin caused microtubular dysfunction, changes in cell morphology, and loss of epithelial barrier function, critical to airway diseases. ${ }^{45}$ Perhaps, most importantly, RNS have also been reported to nitrate catalase, the $\mathrm{H}_{2} \mathrm{O}_{2}$ scavenger used in this study. This nitrated catalase, reported to be increased in BAL fluid and corresponding with increases in nitrotyrosine activity, has decreased function and could further perpetuate increases in $\mathrm{H}_{2} \mathrm{O}_{2} .{ }^{27}$ Thus, the increase in nitrooxidative stress observed in asthma and particularly in SA, could be because of both increases in production of ROS and RNS, as well as decreases in ROS catabolism.

In summary, results from this study reveal an interaction between airway epithelial iNOS, DUOX2, and TPO, which contribute to airway nitro-oxidative regulation. This regulation occurs primarily through a $\mathrm{H}_{2} \mathrm{O}_{2}$ /endogenous peroxidase dependent nitrite oxidation reaction, leading to increases in $3 \mathrm{NT}$. These biochemical events, influenced by the presence of Th1 and Th2 cytokines associated with SA, and involving the highly novel peroxidase TPO, are likely to alter epithelial function and contribute to the pathobiology of this disease. Whether inhibition of these pathways in vivo will improve outcomes in asthma and SA awaits further study.

\section{METHODS}

Subjects. All asthmatic subjects met the American Thoracic Society criteria for the diagnosis of asthma. MMA had an $\mathrm{FEV}_{1}$ of $>60 \%$ predicted, with/without low-moderate dose inhaled CS. SA subjects met the American Thoracic Society workshop definition for severe refractory asthma, including the continuous use of high-dose inhaled CS and/or frequent use of oral CS with continuing symptoms and/or chronic airflow limitation. ${ }^{46} \mathrm{HC}$ had no history of respiratory disease or recent respiratory infection, normal lung function, and no evidence of bronchial hyperresponsiveness. No subjects smoked within the last year or had a history of smoking $>10$ pack-years. The study was approved by the National Jewish and the University of Pittsburgh Institutional Review Boards, and all subjects gave informed consent. Pulmonary function testing, atopy, and FeNO were evaluated as previously described. ${ }^{23,47}$

In addition to the local Pittsburgh SARP cohort, microarray studies were done on epithelial brushings from HC, MMA, and SA subjects from four SARP sites (Cleveland Clinics, University of Pittsburgh, University of Wisconsin and Wake Forest University). These subjects were characterized identically to the University of Pittsburgh subjects described above.

Bronchoscopy and BAL. Bronchoscopy with endobronchial epithelial brushing and BAL was performed as previously described. $^{48,49}$ The bronchial brushings generally comprised $>90 \%$ epithelial cells.

Primary HAEC culture and siRNA transfection. Primary HAEC were cultured in ALI, and siRNA transfection was performed as previously described. ${ }^{49}$ From day 0 of ALI, cells were stimulated with IL-13 (1 or $10 \mathrm{ng} \mathrm{ml}^{-1}, \mathrm{R} \& \mathrm{D}$ Systems, Minneapolis, MN) or medium alone added to the lower chamber every $48 \mathrm{~h}$ for 8 days, with/without exposure to IFN- $\gamma$ (10 or $100 \mathrm{ng} \mathrm{ml}^{-1}$, R\&D Systems) for the last $72 \mathrm{~h}$. DUOX2 siRNA (Invitrogen, Carlsbad, CA) or TPO siRNA (Santa Cruz Biotechnology, Santa Cruz, CA) was transfected into cells using Mirus siQUEST transfection reagent (Mirus, Madison, WI). For transfection experiment, combination of IL-13 $\left(1 \mathrm{ng} \mathrm{ml}^{-1}\right)$ and IFN- $\gamma$ $\left(100 \mathrm{ng} \mathrm{ml}^{-1}\right)$ was initiated at the beginning of ALI culture and continued for $48 \mathrm{~h}$. Scramble siRNA was transfected at the same time as the negative control. 
$\mathrm{H}_{2} \mathrm{O}_{2}$ measurements. Culture medium from the upper chamber was removed on day 8 , and $100 \mu \mathrm{l}$ PBS with/without one of the following was added: catalase $\left(150 \mathrm{U} \mathrm{ml}^{-1}\right.$, Sigma, St Louis, MO), SODpolyethylene glycol from bovine erythrocytes $\left(150 \mathrm{U} \mathrm{ml}^{-1}\right.$, Sigma), nitrite (10 or $25 \mu \mathrm{M}$, Sigma), or the combination of catalase and nitrite. Following $1 \mathrm{~h}$ incubation, $\mathrm{H}_{2} \mathrm{O}_{2}$ was then measured in the upper chamber supernatants using the Amplex Red Hydrogen Peroxide/ Peroxidase Assay Kit (Molecular Probes, Eugene, OR). The fluorescent signal was read at $530 \mathrm{~nm}$ excitation, $590 \mathrm{~nm}$ emission, using the Infinite 200 PRO (Tecan, Männedorf, Switzerland).

Microarray methods. mRNA was extracted from bronchial epithelial cells suspended in Trizol solution using the QIACube system (Qiagen, Valencia, CA). Microarray experiments were performed as we previously reported. ${ }^{50}$ RNA quality was determined using the Agilent Bioanalyzer 2100 (Agilent Technologies, Santa Clara, CA). RNA was hybridized to Agilent Human GE $4 \times 44 \mathrm{~K}$ V2 Gene Expression microarrays. The microarrays were scanned using the Agilent Microarray scanner (Agilent Technologies) and the data was extracted using the Agilent Feature Extraction software 10.7.3.1 (Agilent Technologies). The data was then normalized using a cyclic loess algorithm authored in the $\mathrm{R}$ programming environment using the Bioconductor suite of tools. The resultant data was analyzed using BRB-ArrayTools version 4.3.0 developed by Dr Richard Simon and the BRB-ArrayTools Development Team. Differentially expressed genes were determined by $t$-test using a false discovery rate of 0.05 with a confidence interval of $90 \%$. The data discussed in this manuscript have been deposited in NCBI's Gene Expression Omnibus database (http:// www.ncbi.nlm.nih.gov/geo) and are accessible through Gene Expression Omnibus Series accession number GSE43696.

Quantitative real-time PCR. Real-time PCR was performed on the ABI Prism 7700 sequence detection system (Applied Biosystems, Foster City, CA) as described previously. ${ }^{7}$ The primers and probes were obtained from Applied Biosystems (IFN- $\gamma$, Hs00989291_m1; IL-13, Hs00174379_m1; iNOS, Hs00167248_m1; DUOX2, Hs00204187_m1; TPO, Hs00374171_m1; and GAPDH, 4310884E). TPO primers covered the junction of exons 16 and 17 . The mRNAs of interest were indexed to GAPDH using the formula $1 /\left(2^{\Delta \mathrm{CT}}\right) \times 1,000$.

Western blotting. Samples were resolved on $4-12 \%$ SDS-PAGE and immuno-probed with antibodies for iNOS (1:500, BD Transduction Laboratories, Franklin Lakes, NJ), DUOX2 (1:250, Abcam, Cambridge, MA), TPO (1:100, Santa Cruz), and $\beta$-actin (1:5000, Sigma). The membrane was developed and densitometry was performed using Multi Gauge software (FujiFilm, Stamford, CT). Each image was obtained from the same blot; however, some blot conditions were shown individually as they were rearranged for conceptual clarity.

Nitrite and nitrate measurement. Lower supernatant nitrite and nitrate concentrations were quantified using a colorimetric assay based on the Griess reaction (Parameter Total Nitric Oxide and Nitrite/ Nitrate Assay, R\&D Systems). Briefly, nitrite was quantified and nitrate was converted to nitrite using nitrate reductase, followed by the addition of Griess reagent to produce an azo dye compound. The absorbance was measured at $540 \mathrm{~nm}$. Nitrate concentrations were indirectly determined by subtracting the concentration of nitrite from the basal and converted nitrite concentrations.

3NT measurement. 3NT concentrations in lysates were quantified spectrophotometrically at $600 \mathrm{~nm}$ using a sandwich ELISA (enzymelinked immunosorbent assay) kit (Abcam), with a sensitivity of $8 \mathrm{ng} \mathrm{ml}^{-1}$, intra- and inter-assay variation of 6.9 and $13 \%$, respectively. Samples were measured in duplicate against known standards. Levels of $3 \mathrm{NT}$ were normalized to cellular protein content and expressed in $\mathrm{ng} \mathrm{mg}^{-1}$ protein.

Data and statistical analysis. Statistical analysis was performed using JMP SAS software (SAS Institute Inc., Cary, NC). When possible, data were log transformed to achieve linearity. Ex vivo data were assessed by analysis of covariance, adjusted for age, followed by the Tukey-Kramer test to compare intergroup difference. A two-way repeated measures analysis of variance (ANOVA) was used to determine significant main effects and interactions between IL-13 and IFN- $\gamma$ in in vitro experiments.

The Bonferroni procedure was used to conservatively test for the multiple post hoc comparisons between groups using (1) $\alpha=0.05 /$ $3=0.017$ for comparisons between control vs. IL- $13\left(1,10 \mathrm{ng} \mathrm{ml}^{-1}\right)$ or vs. IFN- $\gamma\left(10,100 \mathrm{ng} \mathrm{ml}^{-1}\right)$; (2) $\alpha=0.05 / 2=0.025$ for comparisons between combined IL-13 plus IFN- $\gamma$ vs. IL-13 alone or vs. IFN- $\gamma$ alone. Correlations were assessed using either the Pearson $r$ (normally distributed data) or the Spearman $\rho$ (non-normally distributed data) coefficients.

SUPPLEMENTARY MATERIAL is linked to the online version of the paper at http://www.nature.com/mi

\section{ACKNOWLEDGMENTS}

We thank $F$ Holguin and $L$ Wang for their statistical advice; $\mathrm{H} \mathrm{Hu}$ and C Uvalle for their excellent technical assistance; AS Larkin, X Zhou, ML Fajt, and RS Traister for their helpful contributions; and L Wang for technical advice and providing nitrite. This study was supported by grants Al67780, HL69174, CTSI UL1-RR024153, RC2HL101487, HL69167, HL69170, HL69116, and the Dellenback Fund.

\section{DISCLOSURE}

The authors declared no conflict of interest.

(c) 2014 Society for Mucosal Immunology

\section{REFERENCES}

1. van der Vliet, A., Eiserich, J.P., O'Neill, C.A., Halliwell, B. \& Cross, C.E. Tyrosine modification by reactive nitrogen species: a closer look. Arch. Biochem. Biophys. 319, 341-349 (1995).

2. Hurst, J.K. Whence nitrotyrosine? J. Clin. Invest. 109, 1287-1289 (2002).

3. Dweik, R.A. et al. NO chemical events in the human airway during the immediate and late antigen-induced asthmatic response. Proc. Natl. Acad. Sci. USA 98, 2622-2627 (2001).

4. MacPherson, J.C. et al. Eosinophils are a major source of nitric oxidederived oxidants in severe asthma: characterization of pathways available to eosinophils for generating reactive nitrogen species. J. Immunol. 166, 5763-5772 (2001).

5. Sugiura, H., Komaki, Y., Koarai, A. \& Ichinose, M. Nitrative stress in refractory asthma. J. Allergy Clin. Immunol. 121, 355-360 (2008).

6. Guo, F.H., De Raeve, H.R., Rice, T.W., Stuehr, D.J., Thunnissen, F.B. \& Erzurum, S.C. Continuous nitric oxide synthesis by inducible nitric oxide synthase in normal human airway epithelium in vivo. Proc. Natl. Acad. Sci. USA 92, 7809-7813 (1995).

7. Chibana, K. etal. IL-13 induced increases in nitrite levels are primarily driven by increases in inducible nitric oxide synthase as compared with effects on arginases in human primary bronchial epithelial cells. Clin. Exp. Allergy 38, 936-946 (2008)

8. Patel, R.P. et al. Biological aspects of reactive nitrogen species. Biochim. Biophys. Acta. 1411, 385-400 (1999).

9. van der Vliet, A., Eiserich, J.P., Halliwell, B. \& Cross, C.E. Formation of reactive nitrogen species during peroxidase-catalyzed oxidation of nitrite. A potential additional mechanism of nitric oxide-dependent toxicity. J. Biol. Chem. 272, 7617-7625 (1997).

10. Eiserich, J.P. et al. Formation of nitric oxide-derived inflammatory oxidants by myeloperoxidase in neutrophils. Nature 391, 393-397 (1998).

11. Brennan, M.L. et al. A tale of two controversies: defining both the role of peroxidases in nitrotyrosine formation in vivo using eosinophil peroxidase and myeloperoxidase-deficient mice, and the nature of peroxidasegenerated reactive nitrogen species. J. Biol. Chem. 277, 17415-17427 (2002).

12. Govindaraju, K., Shan, J., Levesque, K., Hussain, S.N., Powell, W.S. \& Eidelman, D.H. Nitration of respiratory epithelial cells by myeloperoxidase depends on extracellular nitrite. Nitric Oxide 18, 184-194 (2008). 
13. Geiszt, M., Witta, J., Baffi, J., Lekstrom, K. \& Leto, T.L. Dual oxidases represent novel hydrogen peroxide sources supporting mucosal surface host defense. FASEB J. 17, 1502-1504 (2003).

14. Forteza, R., Salathe, M., Miot, F. \& Conner, G.E. Regulated hydrogen peroxide production by Duox in human airway epithelial cells. Am. J. Respir. Cell Mol. Biol. 32, 462-469 (2005).

15. Harper, R.W. et al. Differential regulation of dual NADPH oxidases/ peroxidases, Duox1 and Duox2, by Th1 and Th2 cytokines in respiratory tract epithelium. FEBS Lett. 579, 4911-4917 (2005).

16. Gattas, M.V. et al. Oxidative epithelial host defense is regulated by infectious and inflammatory stimuli. Free Radic. Biol. Med. 47, 1450-1458 (2009).

17. Song, Y. et al. Association of duoxes with thyroid peroxidase and its regulation in thyrocytes. J. Clin. Endocrinol. Metab. 95, 375-382 (2010).

18. Fortunato, R.S. et al. Functional consequences of dual oxidase-thyroperoxidase interaction at the plasma membrane. J. Clin. Endocrinol. Metab. 95, 5403-5411 (2010).

19. Guo, F.H. et al. Molecular mechanisms of increased nitric oxide (NO) in asthma: evidence for transcriptional and post-translational regulation of NO synthesis. J. Immunol. 164, 5970-5980 (2000).

20. Corren, J. et al. A randomized, controlled, phase 2 study of AMG 317, an IL-4Ralpha antagonist, in patients with asthma. Am. J. Respir. Crit. Care Med. 181, 788-796 (2010).

21. Wenzel, S., Wilbraham, D., Fuller, R., Getz, E.B. \& Longphre, M. Effect of an interleukin-4 variant on late phase asthmatic response to allergen challenge in asthmatic patients: results of two phase 2a studies. Lancet 370, 1422-1431 (2007).

22. Guo, F.H. et al. Interferon gamma and interleukin 4 stimulate prolonged expression of inducible nitric oxide synthase in human airway epithelium through synthesis of soluble mediators. J. Clin. Invest. 100, 829-838 (1997).

23. Yamamoto, M., Tochino, Y., Chibana, K., Trudeau, J.B., Holguin, F. \& Wenzel, S.E. Nitric oxide and related enzymes in asthma: relation to severity, enzyme function and inflammation. Clin. Exp. Allergy 42, 760-768 (2012).

24. Harper, R.W., Xu, C., McManus, M., Heidersbach, A. \& Eiserich, J.P. Duox2 exhibits potent heme peroxidase activity in human respiratory tract epithelium. FEBS Lett. 580, 5150-5154 (2006).

25. Andreadis, A.A., Hazen, S.L., Comhair, S.A. \& Erzurum, S.C. Oxidative and nitrosative events in asthma. Free Radic. Biol. Med. 35, 213-225 (2003).

26. Horvath, I. et al. Combined use of exhaled hydrogen peroxide and nitric oxide in monitoring asthma. Am. J. Respir. Crit. Care Med. 158, 1042-1046 (1998).

27. Ghosh, S. et al. Nitrotyrosine proteome survey in asthma identifies oxidative mechanism of catalase inactivation. J. Immunol. 176, 5587-5597 (2006).

28. Duguet, A., lijima, H., Eum, S.Y., Hamid, Q. \& Eidelman, D.H. Eosinophil peroxidase mediates protein nitration in allergic airway inflammation in mice. Am. J. Respir. Crit. Care Med. 164, 1119-1126 (2001).

29. van Dalen, C.J., Winterbourn, C.C., Senthilmohan, R. \& Kettle, A.J. Nitrite as a substrate and inhibitor of myeloperoxidase. Implications for nitration and hypochlorous acid production at sites of inflammation. J. Biol. Chem. 275, 11638-11644 (2000).

30. Baldus, S., Eiserich, J.P., Brennan, M.L., Jackson, R.M., Alexander, C.B. \& Freeman, B.A. Spatial mapping of pulmonary and vascular nitrotyrosine reveals the pivotal role of myeloperoxidase as a catalyst for tyrosine nitration in inflammatory diseases. Free Radic. Biol. Med. 33, 1010 (2002).

31. Hunt, J., Byrns, R.E., Ignarro, L.J. \& Gaston, B. Condensed expirate nitrite as a home marker for acute asthma. Lancet 346, 1235-1236 (1995).
32. Assa'ad, A.H., Ballard, E.T., Sebastian, K.D., Loven, D.P., Boivin, G.P. \& Lierl, M.B. Effect of superoxide dismutase on a rabbit model of chronic allergic asthma. Ann. Allergy Asthma Immunol. 80, 215-224 (1998).

33. Comhair, S.A. \& Erzurum, S.C. Redox control of asthma: molecular mechanisms and therapeutic opportunities. Antioxid. Redox Signal. 12, 93-124 (2010).

34. Bian, K., Gao, Z., Weisbrodt, N. \& Murad, F. The nature of heme/ iron-induced protein tyrosine nitration. Proc. Natl. Acad. Sci. USA 100, 5712-5717 (2003).

35. Reszka, K.J., McCormick, M.L. \& Britigan, B.E. Peroxidase- and nitritedependent metabolism of the anthracycline anticancer agents daunorubicin and doxorubicin. Biochemistry 40, 15349-15361 (2001).

36. De Deken, $X$. et al. Cloning of two human thyroid cDNAs encoding new members of the NADPH oxidase family. J. Biol. Chem. 275, 23227-23233 (2000).

37. Magnusson, R.P. et al. Molecular cloning of the complementary deoxyribonucleic acid for human thyroid peroxidase. Mol. Endocrinol. 1, 856-861 (1987).

38. Ferrand, M., Le Fourn, V. \& Franc, J.L. Increasing diversity of human thyroperoxidase generated by alternative splicing. Characterized by molecular cloning of new transcripts with single- and multispliced mRNAs. J. Biol. Chem. 278, 3793-3800 (2003).

39. Wenzel, S.E. Asthma phenotypes: the evolution from clinical to molecular approaches. Nat. Med. 18, 716-725 (2012).

40. Paludan, S.R., Lovmand, J., Ellermann-Eriksen, S. \& Mogensen, S.C. Effect of IL-4 and IL-13 on IFN-gamma-induced production of nitric oxide in mouse macrophages infected with herpes simplex virus type 2. FEBS Lett. 414, 61-64 (1997).

41. Ruetten, H. \& Thiemermann, C. Interleukin-13 is a more potent inhibitor of the expression of inducible nitric oxide synthase in smooth muscle cells than in macrophages: a comparison with interleukin-4 and interleukin-10. Shock 8, 409-414 (1997).

42. Filosto, S. et al. EGF receptor exposed to oxidative stress acquires abnormal phosphorylation and aberrant activated conformation that impairs canonical dimerization. PLOS ONE 6, e23240 (2011).

43. Nethery, D.E., Ghosh, S., Erzurum, S.C. \& Kern, J.A. Inactivation of neuregulin-1 by nitration. Am. J. Physiol. Lung Cell Mol. Physiol. 292, L287-L293 (2007).

44. Ito, K., Hanazawa, T., Tomita, K., Barnes, P.J. \& Adcock, I.M. Oxidative stress reduces histone deacetylase 2 activity and enhances IL-8 gene expression: role of tyrosine nitration. Biochem. Biophys. Res. Commun. 315, 240-245 (2004).

45. Eiserich, J.P. et al. Microtubule dysfunction by posttranslational nitrotyrosination of alpha-tubulin: a nitric oxide-dependent mechanism of cellular injury. Proc. Natl. Acad. Sci. USA 96, 6365-6370 (1999).

46. Proceedings of the ATS workshop on refractory asthma: current understanding, recommendations, and unanswered questions. American Thoracic Society. Am. J. Respir. Crit. Care Med. 162, 2341-2351 (2000).

47. Moore, W.C. et al. Characterization of the severe asthma phenotype by the National Heart, Lung, and Blood Institute's Severe Asthma Research Program. J. Allergy Clin. Immunol. 119, 405-413 (2007).

48. Chu, H.W. et al. Expression and activation of 15-lipoxygenase pathway in severe asthma: relationship to eosinophilic phenotype and collagen deposition. Clin. Exp. Allergy 32, 1558-1565 (2002).

49. Zhao, J., O'Donnell, V.B., Balzar, S. St, Croix, C.M., Trudeau, J.B. \& Wenzel, S.E. 15-Lipoxygenase 1 interacts with phosphatidylethanolamine-binding protein to regulate MAPK signaling in human airway epithelial cells. Proc. Natl. Acad. Sci. USA 108, 14246-14251 (2011).

50. Milosevic, J. et al. Profibrotic Role of miR-154 in Pulmonary Fibrosis. Am. J. Respir. Cell Mol. Biol. 47, 879-887 (2012). 